\title{
SHIFTS IN TREE ALLOMETRY IN A TROPICAL DRY FOREST: IMPLICATIONS FOR ABOVE-GROUND BIOMASS ESTIMATION
}

\section{CAMBIOS EN LA ALOMETRÍA DE LOS ÁRBOLES EN UNA SELVA TROPICAL SECA: IMPLICACIONES PARA LA ESTIMACIÓN DE LA BIOMASA EPIGEA}

\author{
Gustavo Ramírez-RamíreZ ${ }^{1}$, Luis Ramírez y AVILÉS ${ }^{1}$, Francisco JaVier Solorio-SáncheZ ${ }^{1}$, Jorge Augusto \\ NAVARRo-Alberto ${ }^{1}$, AND JUAN MANUEl DUPUY-RADA ${ }^{2, *}$
}

${ }^{1}$ Universidad Autónoma de Yucatán, Campus de Ciencias Biológicas y Agropecuarias, Mérida, Yucatán, Mexico. ${ }^{2}$ Centro de Investigación Científica de Yucatán, A.C. Unidad de Recursos Naturales, Mérida, Yucatán, Mexico.

*Corresponding author: jmdupuy@cicy.mx

\begin{abstract}
Background: Accurate estimations of aboveground biomass (AGB) based on allometric models are needed to implement climate-change mitigation strategies. However, allometry can change with tree size.

Questions: Does allometry in a tropical dry forest change with tree size? Does combining different allometric equations provide better AGB estimates than using a single equation?

Study site and dates: San Agustín Ejido, Yucatán, Mexico, 2016.

Methods: Forty-seven trees of 18 species with 2.5 to $41.5 \mathrm{~cm}$ in diameter at breast height (DBH) were sampled. Stems and branches were sectioned, and samples were dried and weighed to estimate tree AGB. Segmented linear regression was used to evaluate changes in allometry between DBH, height and AGB. Different equations were tested for each size category identified, and the best models and model-combinations selected.

Results: A shift in the AGB-height relationship was found, defining two tree-size categories $(2.5-9.9 \mathrm{~cm}$ and $\geq 10 \mathrm{~cm}$ in DBH), with the inflection point corresponding to the average canopy height $(12.2 \mathrm{~m})$. The best models were AGB $=\exp \left(-2.769+0.937 \mathrm{ln}\left(\mathrm{D}^{2} \mathrm{HPw}\right)\right)$ for trees $<$ $10 \mathrm{~cm} \mathrm{DBH}$ and $\mathrm{AGB}=\exp (-9.171+1.591 \ln \mathrm{D}+3.902 \operatorname{lnH}+0.496 \ln \mathrm{Pw})$ for trees $\geq 10 \mathrm{~cm} \mathrm{DBH}\left(R^{2}=0.85\right.$ and $R^{2}=0.92$, respectively $)$. The combination of these models produced more accurate AGB estimates than a single model or combinations involving regional models with larger sample sizes.

Conclusions: These results highlight the importance of locally-developed models and suggest changes in allometry and resource allocation: towards height growth for small trees, thereby reducing the risk of suppression, versus towards AGB growth for larger trees, thereby maximizing stability and resource acquisition.
\end{abstract}

Keywords: Allometric equations, growth, resource allocation, segmented regression, tree-size categories.

\section{Resumen}

Antecedentes: Se requieren estimaciones precisas de la biomasa epigea (BE) para la mitigación del cambio climático. Sin embargo, la alometría puede cambiar con el tamaño de los árboles.

Preguntas: La alometría en una selva seca, ¿cambia con el tamaño de los árboles? ¿Conviene combinar diferentes ecuaciones alométricas para estimar la BE?

Sitio de estudio y fechas: Ejido San Agustín, Yucatán, México, 2016.

Métodos: Se muestrearon 47 árboles de 18 especies con 2.5 a $41.5 \mathrm{~cm}$ de diámetro. Se seccionaron tallos y ramas y se tomaron muestras para secarlas, pesarlas y estimar la BE. Se usó regresión lineal segmentada para evaluar cambios en la alometría entre BE, altura y diámetro. Se evaluaron diferentes ecuaciones para cada categoría de tamaño identificada.

Resultados: Se encontró un cambio en la relación BE-altura, definiendo dos categorías de tamaño $(2.5-9.9 \mathrm{~cm}$ y $\geq 10 \mathrm{~cm}$ de diámetro), con un punto de inflexión a la altura promedio del dosel $(12.2 \mathrm{~m})$. Los mejores modelos fueron: $\mathrm{BE}=\exp \left(-2.769+0.937 \mathrm{ln}\left(\mathrm{D}^{2} \mathrm{HPw}\right)\right)$ para árboles pequeños y $\mathrm{BE}=\exp (-9.171+1.591 \ln \mathrm{D}+3.902 \ln \mathrm{H}+0.496 \ln \mathrm{Pw})$ para árboles grandes $\left(R^{2}=0.85\right.$ y $\left.R^{2}=0.92\right)$. La combinación de estos modelos dio estimaciones más precisas que modelos individuales o combinaciones con modelos regionales.

Conclusiones: Estos resultados resaltan la importancia de usar modelos locales y sugieren cambios en la alometría y la asignación de recursos: hacia crecimiento en altura en árboles pequeños, reduciendo el riesgo de ser suprimidos; versus hacia crecimiento en BE en árboles grandes, maximizando su estabilidad y adquisición de recursos.

Palabras clave: Asignación de recursos, categorías de tamaño de los árboles, crecimiento, ecuaciones alométricas, regresión segmentada.

This is an open access article distributed under the terms of the Creative Commons Attribution License CCBY-NC (4.0) international. https://creativecommons.org/licences/by-nc/4.0/ 
Forests function as the main sinks and reservoirs of terrestrial carbon as well as providers of several environmental services (Hui et al. 2016). Global increases in atmospheric carbon dioxide and their effect on climate are driving a growing interest in quantifying forest carbon storage (Pan et al. 2011). Tropical forests contain almost $55 \%$ of the carbon stored in terrestrial vegetation but experience high rates of deforestation and degradation (Hui et al. 2016) which are estimated to cause $6-20 \%$ of anthropogenic greenhouse gas emissions (Dixon et al. 1994, Pan et al. 2011, Baccini et al. 2012, Le Quéré et al. 2015). This releases the carbon that was stored to the atmosphere, transforming the vegetation from a carbon sink into a carbon source. Understanding the magnitude of the greenhouse gas emissions associated with these processes requires accurate quantifications of tropical forest biomass and emission factors (Chaplin-Kramer et al. 2015).

Precise estimation of tropical forest biomass is vital for commercial lumber production and for understanding and modeling the global carbon cycle. The vast majority of the world's nations are committed to provide periodic reports on the condition of their forest resources and on forest emissions and absorptions of green-house gases under the United Nations Framework Convention on Climate Change (UNFCCC 2007). In addition, implementation of climate-change mitigation mechanisms such as the Reduction of Emissions from Deforestation and Degradation (REDD+) requires accurate data on forest carbon reservoirs and emission factors (Angelsen et al. 2012). Secondary tropical forests re-growing after abandonment of agricultural lands currently account for over half of the tropical forest area worldwide (FAO 2010) and are increasingly recognized as playing an important role in the global carbon cycle (Poorter et al. 2016, Chazdon et al. 2016), yet no global estimates of the carbon stock in secondary tropical forests are currently available (Bongers et al. 2015).

Most forest biomass studies focus on above-ground biomass (AGB) since it is relatively easy to estimate, monitor and tie in to remote sensing data (Timothy et al. 2016). However, efforts to quantify AGB and the carbon stored therein in tropical forests have been plagued by uncertainty. For example, estimates made for tropical forests in Africa vary by more than $100 \%$ and in the Amazonian rainforest may vary by up to $60 \%$ (Baccini et al. 2012).

Accurately estimating AGB involves choosing an appropriate biomass allometric model. Allometry allows prediction of one tree measurement (e.g., AGB) as a function of another (e.g., diameter) (Gayon 2000, Picard et al. 2012) which can be further improved by including height and wood density in the models (Chave et al. 2005, Návar-Cháidez et al. 2013, Ramírez-Ramírez et al. 2017). The errors associated with AGB estimation such as the uncertainty inherent in inferring individual tree height without direct and exact measurements should also be reported (Chave et al. 2004, Molto et al. 2013, Chen et al. 2015, Mermoz et al. 2015). Empirical models of AGB estimation have been proposed for a whole region (Feldpausch et al. 2012) or even a biome (Chave et al. 2014). However, local-level allometric studies that evaluate tree height-diameter relationships (H-D) can provide better estimates than regional or global models because tree growth and competition between individuals can vary under different biotic and abiotic conditions (Feldpausch et al. 2012). Yet, locally-developed allometric models are not always validated in secondary forests, which can differ in forest structure and composition from old-growth forests (Stas et al. 2017).

Moreover, resource allocation to different tree parameters (i.e., diameter, height, crown- and/or root cover) can change during tree growth in response to changes in resource availability and environmental and biotic conditions (Weiner 2004) and vary as a function of tree size. For instance, small trees may assign more resources to growth in height in order to reduce the risk of suppression by competitors. Once a height has been reached at which suppression is a minimal risk, resources may be assigned to horizontal growth (diameter, crown and root cover) to guarantee greater stability and resource access. In other words, the allometry of forest trees can change as a function of size (Weiner 2004), implying that different allometric models may be needed for small vs large trees and for young secondary-growth vs older forest stands.

The objectives of the present study were threefold: 1) to develop general allometric equations of AGB for a seasonally dry secondary tropical forest in Yucatán, Mexico; 2) evaluate if the allometric relationship of AGB to tree diameter and/or height changes with tree size; 3 ) evaluate if the combined use of different general allometric equations (for different treesize categories) produces more accurate estimations of AGB than one general equation that assumes a single allometric relationship.

\section{Materials and methods}

Study area. The study was conducted in the "Ejido" (communally-owned land) San Agustín, in the municipalities of Oxkutzcab and Tekax, in the southern portion of the state of Yucatán, Mexico (19 $58^{\prime} 43^{\prime \prime} \mathrm{N}$; 89 $9^{\circ} 29^{\prime} 18^{\prime \prime} \mathrm{W}$ ) in July 2016. The landscape consists of rolling, low-elevation (60-190 $\mathrm{m}$ asl) hills and enclosed plains (Flores-Guido \& Espejel-Carvajal 1994). Climate is warm sub-humid (Aw1 in the Köppen classification as modified by García 1973) with summer rain (May-October) and a marked dry season (November-April). Annual mean temperature is $26^{\circ} \mathrm{C}$, and annual mean precipitation ranges from 1,000 to $1,100 \mathrm{~mm}$ (Dupuy et al. 2012). Vegetation type is seasonally dry tropical forest (50 to $75 \%$ of the trees shed their leaves during the dry season). Mean canopy height varies from 10 to $15 \mathrm{~m}$, although species such as Vitex gaumeri Greem and Caesalpinia mollis (Kunth) Spreng can reach up to $18 \mathrm{~m}$ in height (López-Martínez et al. 2013). Virtually all forests in the study region are secondary, but differ in successional age, following abandonment of traditional slash-and-burn agriculture, practiced from pre-Columbian Mayas to current inhabitants (Barrera-Bassols \& Toledo 2005). Soils vary depending on topographic conditions: shallow Leptosols predominate on the hills while deeper Luvisols and Cambisols are found in the plains (Bautista et al. 2015).

Established in 1968, the San Agustín Ejido encompasses 34,506 ha, of which 7,127 ha are subject to hydrological 
services incentive payments, 2,254 ha are under timber exploitation, and 92 ha are human settlement. Constructing allometric equations of $\mathrm{AGB}$ requires destructive sampling of trees in order to obtain precise measurements of AGB that can subsequently be related to other more easily obtained dasometric measures (e.g., diameter, height). Tree felling for this study was done with the permission of ejido members in the timber exploitation area (Figure 1).

Tree sampling. Since the aim of this study was to develop general allometric equation(s) of AGB for the secondary tropical dry forests of San Agustín, we used data from three 1 ha conglomerates (four $400 \mathrm{~m}^{2}$ plots each) in $\geq 50$ year-old secondary forest stands from a community forest inventory (Dupuy, unpublished data), following the National Forest and Soils Inventory protocol (CONAFOR 2013) to identify the dominant tree species in the studied area. Tree species were sorted by decreasing value of total AGB estimated from these conglomerates following the methodology of Hernández-Stefanoni et al. (2014), and the top 25 species that accounted for $95 \%$ of total AGB were identified. To ensure representativeness of landscape conditions, trees were sampled both on plains and on hills, covering a total area of approximately 0.2 ha. At the request of ejido members, sampling of trees $>10 \mathrm{~cm} \mathrm{DBH}$ was also done along the main road -at a distance of $10 \mathrm{~m}$ or more from the road to minimize edge effects. The entire sampling area consisted of 60-70 years-old secondary forests following abandonment of traditional slash-and-burn agriculture, where large-sized trees can be found. The following tree selection criteria were used: 1) belongs to a dominant species (i.e., one of the top 25 species that account for $95 \%$ of AGB); 2) encompasses the widest possible range of $\mathrm{DBH}$ found in the sampling area; 3) has a straight minimally branched trunk; and 4) has permission to fell granted by ejido members.

A total of 47 trees $(\mathrm{DBH}=2.5-41.5 \mathrm{~cm})$ from 18 species were sampled (Table 1). This is just under the minimum sample size of $\mathrm{n}=50$ recommended by previous studies to construct accurate AGB allometric models (Chave et al. 2004, van Breugel et al. 2011, Picard et al. 2012), but it is the most that our human and funding resources, as well as permission of ejido members, allowed. Diameter at breast height $(\mathrm{DBH})$ was measured at $1.3 \mathrm{~m}$ above ground level before felling, and tree height $(\mathrm{H})$ was measured after felling. The trunk and main branches were divided into 1-1.5 $\mathrm{m} \mathrm{sec-}$ tions; all trunk sections, branches and leaves were weighed in the field, and samples were taken of each section and component: stems (10-15 cm pieces), branches $(20-25 \mathrm{~cm}$ pieces) and leaves ( $c a 1 \mathrm{~kg}$ samples). All samples were dried at $70{ }^{\circ} \mathrm{C}$ to constant weight. The dry weight/fresh weight ratio was used to estimate total biomass for each individual (adding all components and sections), based on the total fresh weight measured in the field.

Statistical analyses. Pairwise relationships between AGB, tree height and DBH were analyzed to assess changes in slope. We used segmented regression in R-studio implemented in the segmented package (Muggeo 2008), which

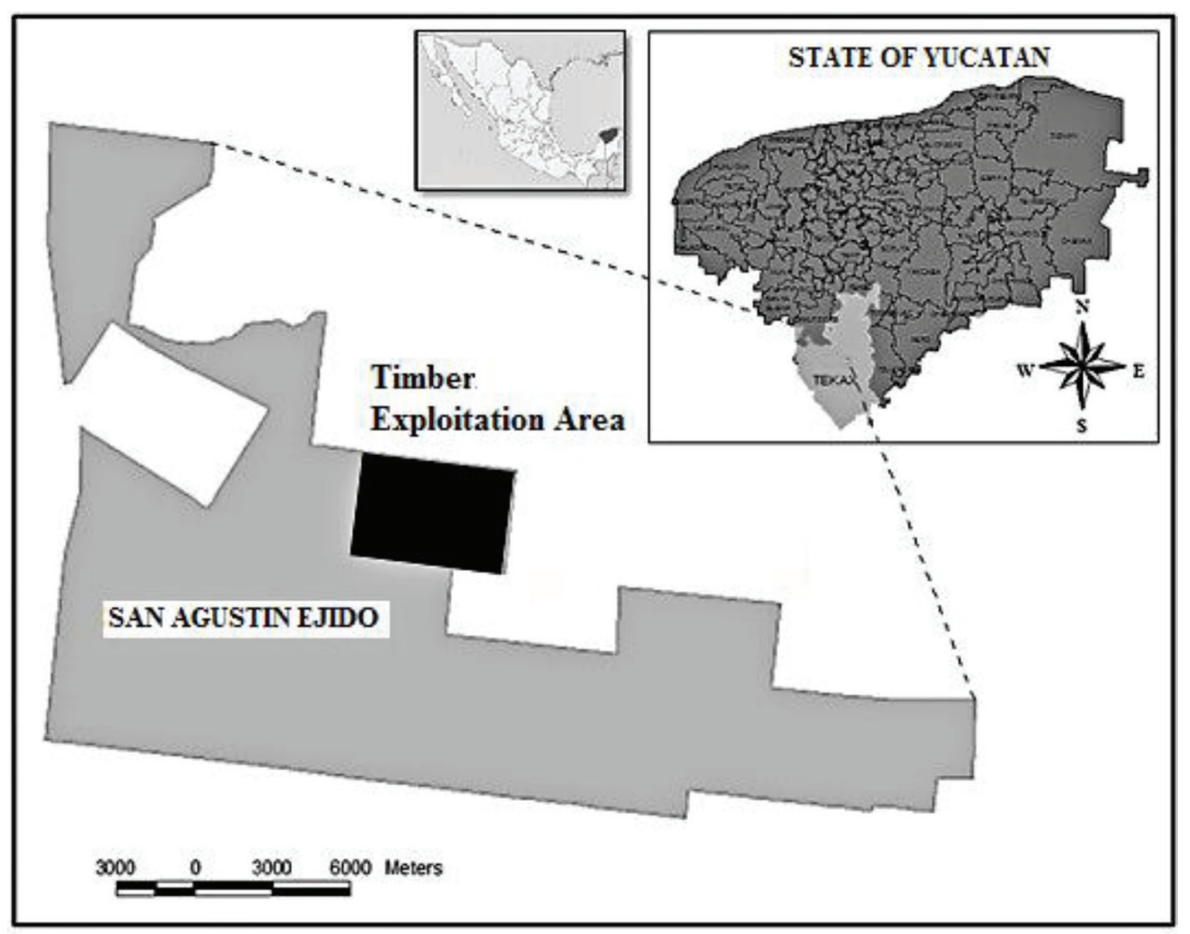

Figure 1. Location of the Timber Exploitation Area, San Agustín Ejido, Yucatán, México, where trees were harvested to construct allometric equations of above ground biomass. Source: Mexico REDD+ Alliance, 2016. 
Table 1. Characteristics of tree species sampled with the destructive method. No. Indiv. $=$ number of individuals; $\mathrm{DBH}=(\mathrm{range}$ of $)$ diameter at breast height $(1.3 \mathrm{~m})$; AGB $=$ (range of) above ground biomass values measured in this study. Ref. wood density = reference for wood density value.

\begin{tabular}{|c|c|c|c|c|c|c|}
\hline Scientific name & No. Indiv. & $\begin{array}{l}\text { DBH } \\
(\mathrm{cm})\end{array}$ & $\begin{array}{l}\text { Height } \\
\text { (m) }\end{array}$ & $\begin{array}{l}\text { Wood density } \\
\qquad\left(\mathrm{g} / \mathrm{cm}^{3}\right)\end{array}$ & $\begin{array}{l}\text { Ref. wood } \\
\text { density }\end{array}$ & $\begin{array}{c}\text { AGB } \\
(\mathrm{kg})\end{array}$ \\
\hline Bunchosia swartziana Griseb. & 1 & 2.9 & 4.6 & 0.58 & $1 *$ & 1.83 \\
\hline Bursera simaruba (L.) Sarg. & 5 & $3.3-38.5$ & $5-13.64$ & 0.36 & $1^{*}$ & $0.67-736.56$ \\
\hline Caesalpinia gaumeri (Britton \& Rose) Greenm. & 2 & $6-6.1$ & $6.9-7.95$ & 0.9 & $1^{*}$ & $6.58-9.04$ \\
\hline Coccoloba diversifolia Jacq. & 2 & $5.5-6.3$ & $8.25-8.76$ & 0.8 & $2 *$ & $9.58-10.25$ \\
\hline Coccoloba spicata Lundell & 2 & $4.1-6$ & $5.93-8.1$ & 0.86 & $1 *$ & $2.96-7.93$ \\
\hline Cochlospermun vitifolium (Willd.) Spreng. & 2 & $10.4-20$ & $10.1-11.35$ & 0.23 & $1^{*}$ & $22.41-60.9$ \\
\hline Exostema caribaeum (Jacq.) Roem. \& Schult. & 1 & 6.7 & 8.55 & 0.88 & $1^{*}$ & 21.15 \\
\hline Gymnopodium floribundum Rolfe. & 2 & $4-6.3$ & $6-8.1$ & 0.79 & $1 *$ & $1.54-13.51$ \\
\hline Lonchocarpus rugosus Benth. & 1 & 6.6 & 10.5 & 0.95 & $1^{*}$ & 15.65 \\
\hline Lonchocarpus xuul Lundell & 7 & $3.3-11.3$ & $5.86-13.2$ & 0.82 & $1 *$ & $2.48-119.2$ \\
\hline Lysiloma latisiliquum (L.) Benth. & 4 & $19.9-37.3$ & $12.2-14.53$ & 0.55 & $1 *$ & $171.06-724.34$ \\
\hline Mimosa bahamensis Benth. & 2 & $5.4-6.5$ & $7-7.31$ & 0.71 & $1^{*}$ & $11.81-17.24$ \\
\hline Melicoccus oliviformis Kunth ssp. oliviformis & 1 & 4.4 & 8.3 & 0.91 & $1^{*}$ & 7.86 \\
\hline Piscidia piscipula (L.) Sarg. & 6 & $4.7-41.5$ & $4.7-12.99$ & 0.78 & $1^{*}$ & $2.64-545.31$ \\
\hline Platymiscium yucatanum Standl. & 2 & $27.6-28.5$ & 13.2513 .55 & 0.9 & $1 *$ & $608.38-777.88$ \\
\hline Psidium sartorianum (O. Berg) Nied. & 2 & $2.5-6.5$ & $4.44-8.24$ & 0.85 & $1^{*}$ & $1.45-17.82$ \\
\hline Thouinia paucidentata Radlk. & 3 & $6-7.5$ & $7-9.57$ & 0.94 & $1 *$ & $10.72-16.34$ \\
\hline Vitex gaumeri Greenm. & 2 & $17.3-38.5$ & $11.28-14.43$ & 0.65 & $1^{*}$ & $106.29-563.91$ \\
\hline
\end{tabular}

1*: Sanaphre-Villanueva et al. 2016; 2*: Chave et al. 2006.

consists of detecting an inflection or break point $(b p)$ in the data and, where found, applying a different linear regression to each segment. Davies' test was applied to identify inflection or break points and to test for significant differences in the slope of the segments (Muggeo 2008). The regression lines were fitted to the data by minimizing the sum of the squared differences (SSD) between the observed value $\left(X_{i}\right)$ and the value calculated by regression $\left(Y_{i}\right)$ of the dependent variable, using the following formulas:

$$
\begin{aligned}
& \log \left(Y_{i}\right)=\beta_{0}+\theta_{1} \log \left(X_{i}\right) \text { for } X_{i}<b p \\
& \log \left(Y_{i}\right)=\beta_{1}+\theta_{2} \log \left(X_{i}\right) \text { for } X_{i}>b p
\end{aligned}
$$

Where

$\theta_{1}$ and $\theta_{2}$ are the regression coefficients indicating the slope of the lines in the respective segments. $\beta_{0}$ and $\beta_{1}$ are the intercepts of each segment, indicating the values of $Y_{i}$ when $X_{i}=0$.

Different allometric equations were then explored for the tree size categories identified with the segmented regressions. These took various functional forms, mainly logarithmic and power, based on common published models (Chave et al. 2005, Picard et al. 2012, Návar-Cháidez et al. 2013, Ramírez-Ramírez et al. 2017). After formally testing that the residuals of each regression equation met the assumptions of normality (Shapiro-Wilk's test) and homoscedasticity
(Breusch-Pagan's test), the sign of the coefficients of the explanatory variables was verified because a positive relationship is expected between $\mathrm{AGB}$ and $\mathrm{DBH}, \mathrm{H}$ and wood density $(\mathrm{Pw})$, and their combinations (e.g., $\left.\mathrm{D}^{2} \mathrm{H}\right)$. Data on $\mathrm{Pw}$ were obtained from previous studies in the region and from the literature (Table 1).

Following the methodologies proposed by Hernández-Stefanoni \& Dupuy (2008), Segura \& Andrade (2008), Fonseca et al. (2009), and Ramírez-Ramírez et al. (2017), selection of those equations with the best goodness of fit and lowest prediction error for each category followed two steps using R (R Core Team 2018):

i. Calculation of equation fit indicators: root mean square error (RMSE); Akaike's Information Criterion (AIC); delta $\operatorname{AIC}(\Delta)$; and Akaike weight $\left(\omega_{i}\right)$ (Caballero 2011). All equations with $\omega_{i}<0.1$ and/or $\Delta>2$ were excluded (HernándezStefanoni \& Dupuy 2008).

$$
A I C=2 k-2 \ln (L),
$$

where:

$k$ is the number of parameters and $L$ is the likelihood function.

Delta $\operatorname{AIC}(\Delta)$

$$
\Delta_{i}=A I C_{i}-\min (A I C)
$$


Akaike weight $\left(\omega_{i}\right)$ :

$$
\omega_{i}=\frac{\exp \left\{-\frac{1}{2} \Delta_{i}\right\}}{\sum_{k=1}^{K}\left\{-\frac{1}{2} \Delta_{k}\right\}}
$$

ii. Cross-validation: following Hernández-Stefanoni et al. (2014), we used leave-one-out cross-validation, in which one datum is excluded at a time and the remaining data are used to generate the corresponding predicted value. This was done for all the data points such that, for each equation, one predicted value was generated for each observed value. A linear regression was then run using the observed and predicted values to select the best equation based on the coefficient of determination $\left(R^{2}\right)$, the agreement coefficient (AC) and the root mean square error (RMSE).

The following is the formula for calculating the agreement coefficient (AC):

$$
A C=1-\frac{S S D}{S P O D}
$$

where

$$
S S D=\sum_{i=1}^{n}\left(X_{i}-Y_{i}\right)^{2}
$$

$X_{i}$ are the observed values of AGB and $Y_{i}$ are the predicted values of $\mathrm{AGB}$,

$$
S P O D=\sum_{i=1}^{n}|\bar{X}-\bar{Y}|\left|X_{i}-\bar{X}\right|\left(|\bar{X}-\bar{Y}|\left|Y_{i}-\bar{Y}\right|\right) .
$$

$\bar{X}$ is the observed mean value of AGB and $\bar{Y}$ is the predicted mean value of AGB.

The equations thus developed for each tree size category were then combined to assess the accuracy of AGB estimation obtained with combinations of equations for the different tree size categories. First, the combination of the most accurate equation for each category was compared to the most accurate single equation developed for the same data set. Second, the most accurate equation developed in the present study was combined with the equations of Brown (1997), Chave et al. (2005) and Urquiza-Haas et al. (2007), all developed and/or validated, and used to estimate AGB in the forests of the Yucatan Peninsula. The most accurate combination was identified by comparing deviation measurements of the models: modelling efficiency (MEF); model coefficient of determination (CD); and coefficient of error (CE) (Medina-Peralta et al. 2010). The MEF statistic is equivalent to the Pearson's correlation coefficient (r) and represents the proportion of the variation expressed by the line $y=z$; in a perfect fit both statistics would have a value of one (Tedeschi 2006, Medina-Peralta et al. 2010). Modelling efficiency (MEF) was calculated as follows:

$$
M E F=1-\frac{\sum_{i=1}^{n}\left(y_{i}-z_{i}\right)^{2}}{\sum_{i=1}^{n}\left(y_{i}-\bar{y}\right)^{2}}
$$

Where $y_{i}$ is the $i$-th observed value; $\bar{y}$ is the arithmetical mean of the observed values; and $z_{i}$ is the $i$-th value predicted by the model combination to be validated. The upper limit of MEF is one (Loague \& Green 1991, Tedeschi 2006, Medina-Peralta et al. 2010), and, because it can be negative (Loague \& Green 1991), the (theoretical) lower limit is minus infinity (Tedeschi 2006). If MEF $<0$, the value predicted by the model combinations is worse than just using $\bar{y}$, the observed mean (Loague \& Green 1991, Medina-Peralta e al. 2010).

The coefficient of determination (CD) was calculated as follows:

$$
C D=\frac{\sum_{i=1}^{n}\left(y_{i}-\bar{y}\right)^{2}}{\sum_{i=1}^{n}\left(z_{i}-\bar{y}\right)^{2}}
$$

It indicates the proportion of the total variation in the observed data that is explained by the predicted data (Loague $\&$ Green, 1991). A CD value near one indicates an accurate prediction by the model, $\mathrm{CD}<1$ indicates overestimation, and $\mathrm{CD}>1$ indicates underestimation (Tedeschi 2006).

The coefficient of error (CE) was calculated using this formula:

$$
C E=\frac{\frac{\sum_{i=1}^{n}\left|y_{i}-z_{i}\right|}{n}}{\bar{y}}
$$

It is a measure of the average of the absolute differences and is expressed as a proportion of the mean of the observed values (Klepper \& Rouse 1991, Medina-Peralta et al. 2010). A value for $\mathrm{C}$ very near zero indicates the model combination yields negligible estimation errors (Yang et al. 2000, Medina-Peralta et al. 2010).

\section{Results}

Allometric relationships between $A G B$, diameter and height. Diameter at breast height (DBH) of the 47 sampled trees averaged $12.67 \mathrm{~cm}($ range $=2.5-41.5 \mathrm{~cm})$, height $(\mathrm{H})$ averaged $9.48 \mathrm{~m}$ (range $=4.44-14.53 \mathrm{~m})$, and AGB averaged $134.25 \mathrm{~kg}$ (range $=0.67-777.88 \mathrm{~kg}$ ), equivalent to $63.1 \mathrm{~kg}$ of carbon (range $=0.31-365.60 \mathrm{~kg}$ ).

The segmented regression analysis indicated a continuous relationship (without segments) between AGB and DBH (Figure 2a), as well as between $\mathrm{H}$ and DBH (Figure 2c), and identified a discontinuity or segmentation in the relationship between $\mathrm{H}$ and AGB (Figure 2b). This analysis identified a break point at $12.18 \mathrm{~m}$ in $\mathrm{H}$ (corresponding to $9.95 \mathrm{~cm}$ in $\mathrm{DBH}$ ), defining two tree size categories: category 1 containing 30 individuals with DBH between 2.5 and $9.95 \mathrm{~cm}$, and category 2 containing 17 individuals with $\mathrm{DBH} \geq 10 \mathrm{~cm}$. Davies' test confirmed that two equations with significantly different slopes should be applied to the AGB-H relationship (Table 2; Figure 2). 

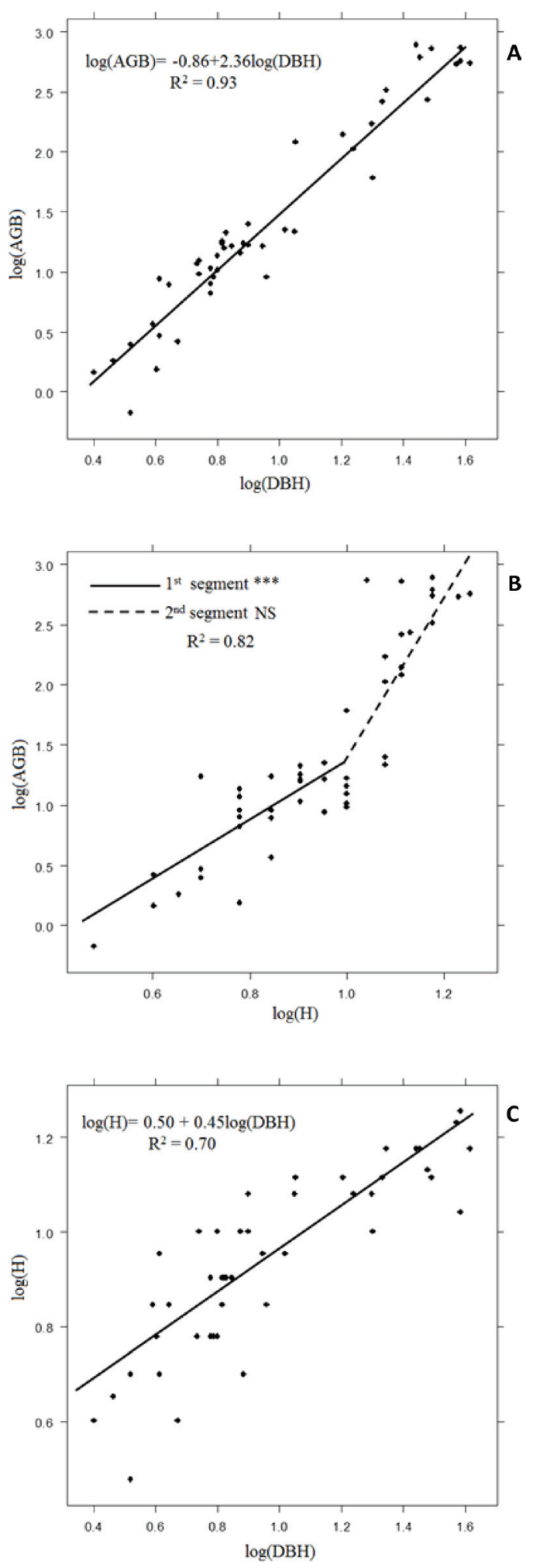

Figure 2. Segmented or linear regression analyses of tree aboveground biomass (AGB) vs diameter at breast height (DBH) (A), AGB vs height $(\mathrm{H})(\mathrm{B})$, and height $(\mathrm{H})$ vs $\mathrm{DBH}(\mathrm{C})$ in a seasonally dry tropical forest in Yucatán, México. ${ }^{* * *}=p<0.001$; NS $=$ not significant.
Table 2. Slopes of the two equations for above-ground biomass (AGB) as a function of tree height (H) defined by segmented regression and Davies' test.

\begin{tabular}{lcccc}
\hline Description & Estimate & Std. Error & t value & $\operatorname{Pr}(>|\mathbf{t}|)$ \\
\hline Intercept & 3.018 & 1.072 & -2.815 & $0.007^{* * *}$ \\
$\operatorname{logH}$ & 2.702 & 0.579 & 4.664 & $3.02 \mathrm{e}-05^{* * * *}$ \\
U1. $\log \mathrm{H}$ & 4.215 & 1.132 & 3.722 & $\mathrm{NS}$ \\
\hline
\end{tabular}

Allometric equations by diameter category. Three allometric equations that met methodological criteria were chosen for tree size category 1 (trees $2.5-9.95 \mathrm{~cm} \mathrm{DBH}$; Table $3)$. The best goodness of fit corresponded to equation 1 : $\mathrm{AGB}=\exp \left(-2.769+0.937 \ln \left(\mathrm{D}^{2} \mathrm{HPw}\right)\left(R_{\text {adj }}^{2}=0.85, \mathrm{AIC}=\right.\right.$ $\left.28.31, \omega_{\mathrm{i}}=0.847\right)$. This equation is based on an exponential relationship, considers a quadratic term for DBH and assumes a multiplicative relationship. The remaining equations were excluded because they had Akaike weight $\left(\omega_{\mathrm{i}}\right)$ values $<0.1$ and/or a $\Delta \mathrm{AIC}>2$ (Table 3 ). Equation 1 also provided the most accurate prediction according to the cross-validation analyses $\left(R_{\text {adj }}^{2}=0.708 ; \mathrm{AC}=0.671\right.$, indicative of a good agreement), as well as the lowest error $(\mathrm{RMSE}=3.26 \mathrm{~kg}$ ). This equation deviated little from the 1:1 relationship line between observed and predicted values, indicating that the estimation bias was negligible (Figure 3a).

Three allometric equations (4 to 6) met the methodological criteria for tree size category 2 (trees $\geq 10 \mathrm{~cm} \mathrm{DBH}$ ). Equation 4 had the best fit $\left(R_{\text {adj }}^{2}=0.92, \mathrm{AIC}=15.67, \omega_{\mathrm{i}}=\right.$ 0.965 ), while the remaining equations were excluded because they had a $\Delta$ AIC $>2$ and Akaike weight $\left(\omega_{i}\right)$ values $<0.1$ (Table 4). Equation 4 assumes an additive relationship and includes $\mathrm{H}$ even though the segmented regression indicated that this variable does not significantly explain biomass variation in this diameter category. The cross-validation analysis produced an $\mathrm{AC}$ value of 0.365 for equation 4, which is indicative of a weak agreement, meaning it has a poor predictive power. Moreover, the estimation error for this equation was very large $(\mathrm{RMSE}=147.65 \mathrm{~kg})$, and the fitted regression line deviated from the 1:1 relationship between predicted and observed values, indicating a bias in AGB estimation: slight overestimation for small trees and larger underestimation for large trees (Figure 3b).

Performance of equation combinations versus a single equation. The best single general equation developed using the whole data set (without separating tree-size categories) was $\mathrm{AGB}=\exp \left(-3.073+1.024 \ln \left(\mathrm{D}^{2} \mathrm{HPw}\right)\right.$. Cross validation analyses for this equation and for the combination of equations 1 and 4 clearly showed that the single equation had lower accuracy $\left(R^{2}=0.68\right.$ versus $\left.R^{2}=0.84\right)$ and higher prediction error $(\mathrm{RMSE}=127.77 \mathrm{~kg}$ versus $\mathrm{RMSE}=92.33 \mathrm{~kg})$ than the 1-4 equation combination (Table 5). Measures of deviation (MEF, CD and CE) confirmed the better performance of the 1-4 equation combination, compared to the best single equation. 
Table 3. General allometric equations developed for tree size category $1(2.5-9.95 \mathrm{~cm}$ in DBH) in a seasonally dry tropical forest in Yucatán, México; $\mathrm{n}=30$.

\begin{tabular}{|c|c|c|c|c|c|c|}
\hline No & Equation & $R_{\text {adj }}^{2}$ & RMSE & AIC & $\Delta$ & $\omega_{i}$ \\
\hline 1 & $\mathrm{AGB}=\exp (-2.769+0.937 \ln (\mathrm{D} 2 \mathrm{HrPw}))$ & 0.85 & 1.42 & 28.31 & 0.00 & 0.847 \\
\hline 2 & $\mathrm{AGB}=\exp (-2.937+1.737 \ln (\mathrm{D})+1.133 \ln (\mathrm{Hr})+0.913 \ln (\mathrm{Pw}))$ & 0.84 & 1.42 & 32.14 & 3.83 & 0.125 \\
\hline 3 & $\mathrm{AGB}=\exp (-1.857+2.458 \ln (\mathrm{D})+1.029 \ln (\mathrm{Pw}))$ & 0.82 & 1.47 & 35.33 & 7.02 & 0.025 \\
\hline
\end{tabular}

$\mathrm{AGB}=$ above-ground biomass $(\mathrm{kg}) ; \mathrm{D}=$ tree diameter $(\mathrm{cm}) ; \mathrm{H}=$ total tree height $(\mathrm{m}) ; \mathrm{Pw}=$ wood density $\left(\mathrm{g} / \mathrm{cm}^{3}\right) ; R_{\text {adj }}^{2}=$ adjusted coefficient of determination; RMSE = root mean square error; AIC = Akaike information criterion; $\Delta=$ deltaAIC; $\omega_{\mathrm{i}}=$ Akaike weight.
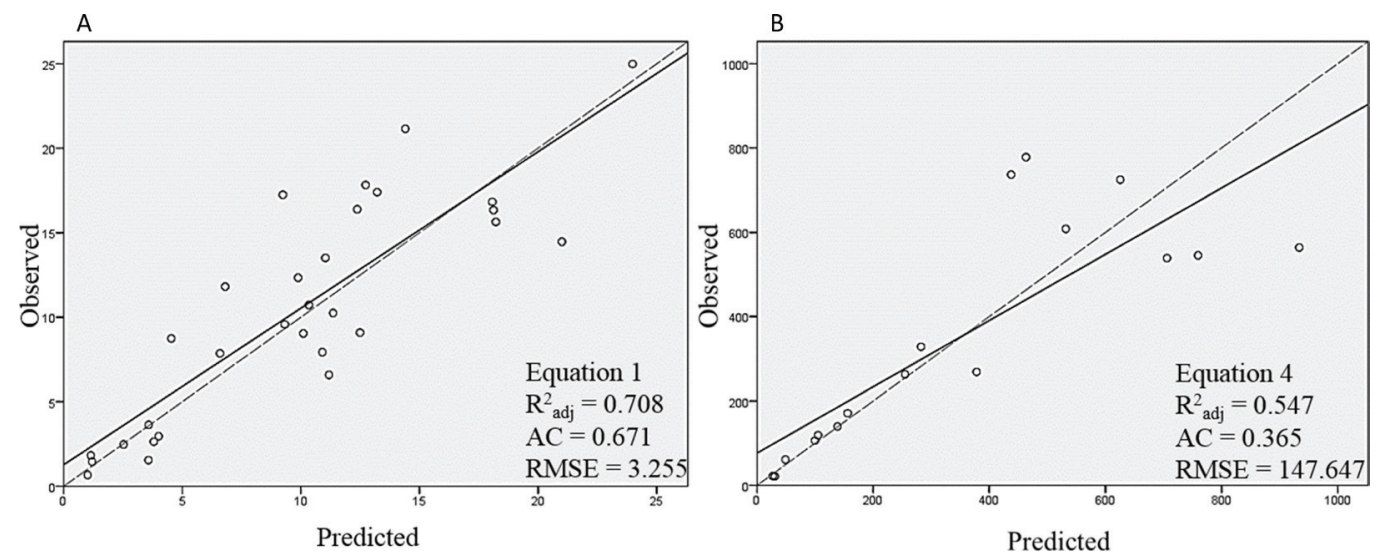

Figure 3. Cross-validation analyses of equations 1 and 4 used to compare observed and predicted tree AGB (kg) values in a seasonally dry tropical forest in Yucatán, México. $R_{\text {adj }}^{2}=$ adjusted coefficient of determination; AC = agreement coefficient; RMSE = root mean square error. The dashed line represents the 1:1 relationship between observed and predicted values. If the fitted line falls above the dashed line, the fitted model overestimates the observed value, and if the fitted line falls below the dashed line, the model underestimates it.

Comparison of combinations of local allometric equations to equations developed or used in the Yucatan Peninsula. The combination of equation 1 with that of Chave et al. (2005) showed slightly higher accuracy than the 1-4 equation combination $\left(R^{2}=0.84\right.$ and $R^{2}=0.83$, respectively) and smaller prediction error $(\mathrm{RMSE}=90.55 \mathrm{~kg}$, and $\mathrm{RMSE}=92.33$ $\mathrm{kg}$, respectively; Figure 4). However, the 1- Chave et al. (2005) equation combination greatly underestimated AGB, especially for large trees, as evidenced by the large deviation of the fitted regression line from the 1:1 relationship between predicted and observed values (Figure 4c). The combination of equation 1 with that of Urquiza-Haas et al. (2007) yielded slightly lower accuracy than the 1-4 equation combination $\left(R^{2}=0.81\right.$ and $R^{2}=0.83$, respectively) and higher estimation error $(\mathrm{RMSE}=98.55 \mathrm{~kg}$, and $\mathrm{RMSE}=92.33 \mathrm{~kg}$, respec- tively). Moreover, compared to the 1-4 equation combination, the1- Urquiza-Haas et al. (2007) combination showed a slightly higher bias, with a tendency towards overestimating AGB, particularly for larger trees (Figure 5a, d). Although the 1- Brown (1997) equation combination showed the lowest accuracy $\left(R^{2}=0.78\right)$ and highest prediction error (RMSE $=105.71 \mathrm{~kg}$ ), it also showed the lowest prediction bias, as shown by the very small deviation of the fitted line from the 1:1 relationship (Figure 5b).

\section{Discussion}

Allometric relationships between $A G B$, diameter and height. Exploration of the allometric relationships between AGB, $\mathrm{DBH}$ and $\mathrm{H}$ for the sampled trees identified a discontinuity

Table 4. General allometric equations developed for tree size category $2(\geq 10 \mathrm{~cm}$ in DBH) in a seasonally dry tropical forest in Yucatán, México; $\mathrm{n}=17$.

\begin{tabular}{|c|c|c|c|c|c|c|}
\hline No & Equation & $R_{\text {adj }}^{2}$ & RMSE & AIC & $\Delta$ & $\omega_{i}$ \\
\hline 4 & $\mathrm{AGB}=\exp (-9.171+1.591 \ln \mathrm{D}+3.902 \ln H r+0.496 \ln \mathrm{Pw})$ & 0.92 & 1.33 & 15.67 & 0.00 & 0.965 \\
\hline 5 & $\mathrm{AGB}=\exp (-1.113+2.223 \ln \mathrm{D}+0.748 \ln \mathrm{Pw})$ & 0.84 & 1.53 & 27.30 & 11.64 & 0.003 \\
\hline 6 & $\mathrm{AGB}=\exp \left(-4.063+1.079 \ln \left(\mathrm{D}^{2} \mathrm{Hr}\right)\right)$ & 0.82 & 1.60 & 28.37 & 12.70 & 0.001 \\
\hline
\end{tabular}

$\mathrm{AGB}=$ above-ground biomass $(\mathrm{kg}) ; \mathrm{D}=$ tree diameter $(\mathrm{cm}) ; \mathrm{H}=$ total tree height $(\mathrm{m}) ; \mathrm{Pw}=$ wood density $\left(\mathrm{g} / \mathrm{cm}^{3}\right) ; R_{\text {adj }}^{2}=$ adjusted coefficient of determination; RMSE = root mean square error; AIC = Akaike information criterion; $\Delta=$ deltaAIC; $\omega_{\mathrm{i}}=$ Akaike weight. 
only in the AGB-H relationship, which suggests a change in tree allometry between AGB and H (Figure 2b). This highlights the importance of analyzing all relationships between the different measurements included in allometric equations. The discontinuity or change in the AGB-H relationship oc-

Table 5. Measures of goodness of fit and deviation to evaluate allometric equations of tree AGB in a seasonally dry tropical forest in Yucatán, México.

\begin{tabular}{lccccc}
\hline Equations & $\boldsymbol{R}_{\text {adj }}{ }^{2}$ & RMSE & MEF & CD & C \\
\hline Single Equation & 0.677 & 127.773 & 0.753 & 0.938 & 0.337 \\
Eq1-4 & 0.835 & 92.33 & 0.835 & 1.197 & 0.337 \\
Eq1-Bro & 0.784 & 105.71 & 0.784 & 1.275 & 0.432 \\
Eq1-Cha & 0.842 & 90.55 & 0.842 & 1.188 & 0.339 \\
Eq1-Urq & 0.813 & 98.55 & 0.812 & 1.231 & 0.342 \\
\hline
\end{tabular}

Eq1-4: combination of equations 1 and 4; Eq1-Bro: combination of equations 1 and Brown (1997); Eq1-Cha: combination of equations 1 and Chave et al. (2005); Eq1-Urq: combination of equations 1 and Urquiza-Haas et al. (2007); RMSE = root mean square error; MEF: modeling efficiency; $\mathrm{CD}$ : equation coefficient of determination; $\mathrm{CE}$ : coefficient of error. curred at a height of $12.2 \mathrm{~m}$, which corresponds to average canopy height in old-growth $(\geq 50$-year-old) forests in the study area (Dupuy et al. 2012). That the segmented regression identified two different segments or relationships between AGB and H, suggests a change in tree growth strategy as a function of height. In particular, the lower slope of the first segment indicates a small increase in AGB for any given increase in $\mathrm{H}$ in trees shorter than the inflexion point of $12.2 \mathrm{~m}$ height, i.e. the average forest canopy height. In other words, small trees $(<10 \mathrm{~cm} \mathrm{DBH})$ seem to assign resources mainly to growth in height (rather than in AGB), which may allow them to reach the canopy in short time periods and avoid suppression by competitors. Once they have reached the canopy, trees may assign resources to horizontal growth (in AGB, diameter, and crown and root cover). This could provide greater mechanical resistance against possible disturbances such as wind, as well as greater access to resources, both above-ground (light) and below-ground (water, nutrients). In agreement with this interpretation, branches contributed a lower percentage of total ABG (28.9\%) in the small tree size category $(\mathrm{DBH}=2.5-9.95 \mathrm{~cm}$; corresponding to trees of $\mathrm{H}<12.2 \mathrm{~m})$, compared to $42 \%$ for the large size category $(\mathrm{DBH}>10 \mathrm{~cm} ; \mathrm{H}>12.2 \mathrm{~m}$; data not shown).
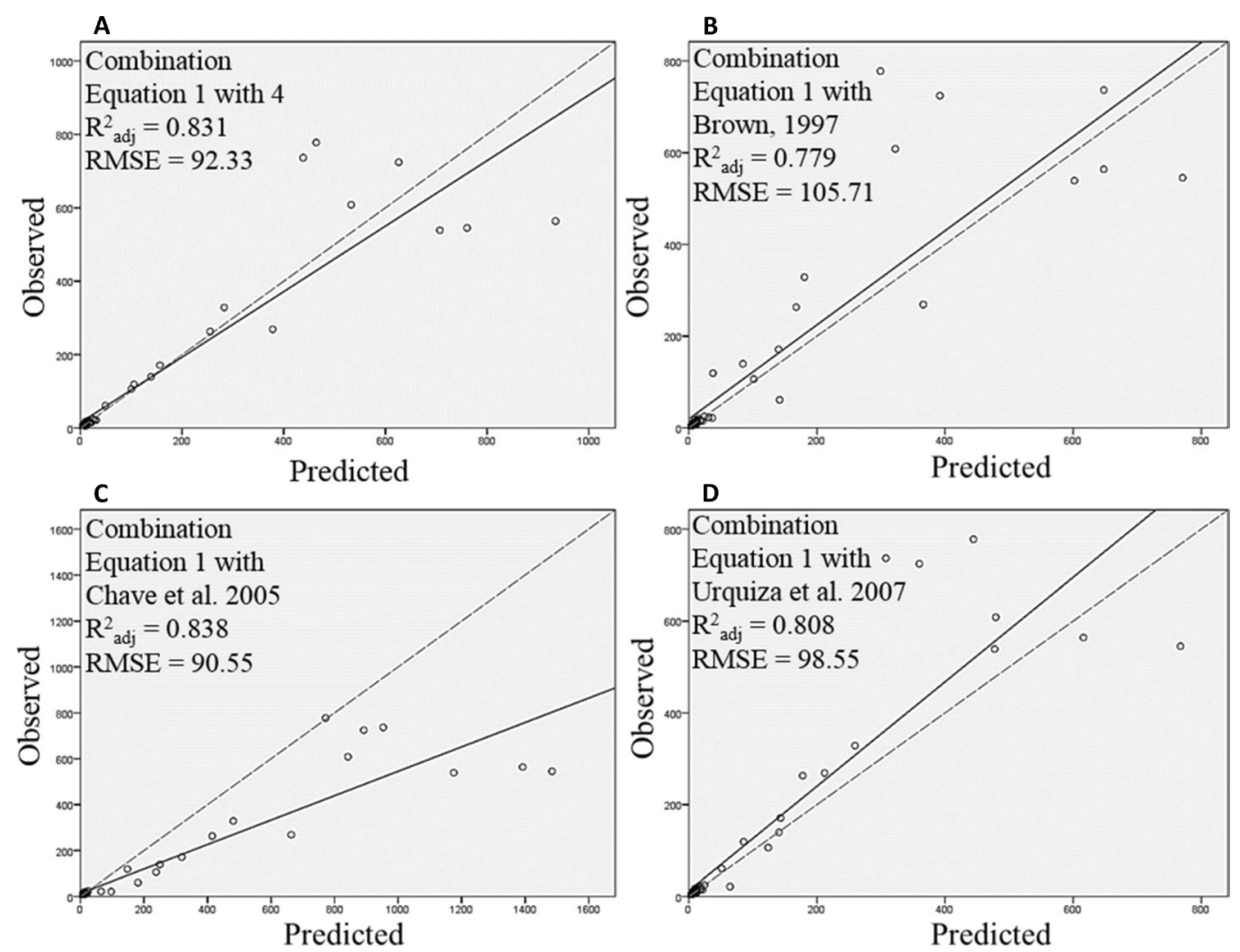

Figure 4. Cross-validation analysis comparing observed and predicted tree AGB (kg) values in a seasonally dry tropical forest in Yucatán, México, for the combination of equations 1 and 4 (A), and for the combinations of equation 1 with those of Brown 1997 (B), Chave et al. 2005 (C) and Urquiza-Haas et al. 2007 (D). $R_{\text {adj }}^{2}=$ adjusted coefficient of determination, RMSE = root mean square error. The dashed line represents the 1:1 relationship between observed and predicted values. If the fitted line falls above the dashed line, the fitted model overestimates the observed value, and if the fitted line falls below the dashed line, the model underestimates it. 
Previous studies (Niklas 1995, Midgley 2003) indicate that trees that assign resources to diameter growth have marginal increases in height, suggesting the existence of mechanical and physiological limits in trees to increasing growth in height. No significant discontinuity between DBH and $\mathrm{H}$ was observed in the present study, although, compared to small trees, larger ones tended to show smaller increases in $\mathrm{H}$ for a given increase in DBH (Figure $2 \mathrm{c}$ ). The change in tree allometry detected in this study implies that using two different allometric equations could be more appropriate and produce more accurate AGB estimations than using a single equation.

Comparisons of allometric equations. The low predictive power of equation 4 (tree size category $2: \geq 10 \mathrm{~cm}$ in DBH) evidenced by the cross-validation analysis may be due in part to the small sample size of this category (17 trees) and highlights the need to increase the sample size of large trees in the studied area. Návar-Cháidez et al. (2013) also found greater uncertainty in AGB estimation for larger $(>10 \mathrm{~cm}$ DBH) trees than for smaller ones in a tropical dry forest in northern Mexico. However, when equation 4 was combined with equation 1 (tree size category 1: $2.5 \mathrm{~cm}-9.9 \mathrm{~cm}$ in $\mathrm{DBH})$, the combination yielded fairly accurate estimates of AGB (Figure 4, Table 5). This was partly due to the good fit and high accuracy of equation 1 (Figure 3), which partly compensated the low accuracy of equation 4. More importantly, the better fit and predictive power of the equations 1-4 combination compared to the best single equation developed for the same data set (Table 5) clearly shows that combining different equations for two tree-size classes can provide more precise estimates of AGB than using a single equation. We propose that this is because using two different equations allows greater flexibility to model shifts in allometry (and resource allocation to growth) before vs after trees reach the forest canopy -as evidenced by the previously discussed discontinuity in the AGB-H relationship. Indeed, the best equations for the two tree size categories (equations 1 and 4 , respectively) differ not only in their parameter values, but also in the type of relationship between dependent and independent variables -multiplicative in the case of equation 1 , additive in the case of equation 4 (Tables 3,4).

Since the allometric equations developed for diameter category 2 were based on a small sample size and showed a low predictive power, we tested if combining equation 1 of this study with other general equations developed and/or validated and used to estimate AGB in the forests of the Yucatan Peninsula, and generally based on larger sample sizes, would yield more accurate estimates. The comparatively low accuracy and high prediction error of the equations 1- Brown (1997) combination vis a vis the equations 1-4 combination (Table 5; Figure 4) was expected, since Brown's equation was developed in a different continent (Asia), based on a small sample size (28 trees) and a narrow range of tree sizes (5- 40 $\mathrm{cm}$ in $\mathrm{DBH}$ ), and did not include tree height or wood density. However, the small estimation bias of this equations combination is surprising, but agrees with the good performance of Brown's (1997) equation compared to a single equation developed using almost the same data set (Ramírez-Ramírez et al. 2017). Conversely, the slightly higher accuracy and lower prediction error of the equations 1- Chave et al. (2005) combination compared to the $1-4$ combination may be partly due to the very large sample size $(\mathrm{n}=1,808)$ of the Chave $e t$ al. (2005) equation, develop for pantropical seasonally dry forests, including those from the Yucatan Peninsula. Nevertheless, the equations 1- Chave et al. (2005) combination largely underestimates AGB, especially for large trees, and therefore should not be applied to our studied area. Finally, the relatively similar overall performance of the equations 1Urquiza-Haas et al. (2007) combination compared to the 1-4 combination, may be partly related to the fact that both equations were developed in the Yucatan Peninsula (although in different locations), and consequently share some dominant tree species (e.g. Coccoloba diversifolia Jacq, Melicoccus oliviformis Kunth ssp. oliviformis), as well as similar climatic and edaphic conditions. Overall, these results suggest that local equations are better suited to local data, even if they are based on relatively small sample sizes.

Caveats, implications for and applications to forest management. Our results have important implications for and applications to forest management. First, our results indicate that using different allometric equations for small $(2.5-9.9 \mathrm{~cm}$ in $\mathrm{DBH})$ than for larger trees $(\geq 10 \mathrm{~cm}$ in $\mathrm{DBH})$ improved the precision of AGB estimation in the studied forest, compared to a single equation, likely because different equations capture shifts in tree allometry and resource allocation to growth. Appropriate and precise allometric equations for AGB estimation are a crucial tool for accurately quantifying forest carbon stocks and emission factors (Malhi et al. 2006, Pan et al. 2011, Anderson-Teixeira et al. 2015, Jucker et al. 2017). Thus, the equations developed in this study may improve estimates of AGB and emission factors in the studied tropical dry forest and, potentially, in similar tropical dry forests of the Yucatán Peninsula.

However, we would like to acknowledge two important caveats of this study: sample size and among-species variation in tree allometry. Due to human and funding constraints, as well as to permission of ejido members to fell only a limited number of trees, the sample size of this study ( $\mathrm{n}=$ 47) fell just short of the minimum $(n=50)$ recommended by previous studies for constructing accurate allometric equations of AGB (Chave et al. 2004, van Breugel et al. 2011, Picard et al. 2012). This problem was particularly evident for large trees, since only 17 trees with $\mathrm{DBH} \geq 10 \mathrm{~cm}$ could be harvested, resulting in a low estimation accuracy $\left(R_{\text {ajd }}^{2}\right.$ $=0.55)$ and a very large estimation error $(\mathrm{RMSE}=147.65$ $\mathrm{kg}$ : Figure 3b). This means that our estimates may not accurately represent actual AGB values of the seasonally dry tropical forests studied -at least for large trees. However, cross validation of equation 1 (for trees $<10 \mathrm{~cm}$ in DBH) showed a relatively high accuracy $\left(R_{\text {ajd }}^{2}=0.71\right)$ and a very low estimation error $($ RMSE $=3.26 \mathrm{~kg}$ : Figure $3 \mathrm{a})$, although the sample size $(n=30)$ was still considerably lower than the minimum recommended $(\mathrm{n}=50)$. Besides, previous studies have successfully developed and validated general allometric 
equations based on small sample sizes $(n=28$ in Brown 1997; n = 39 in Návar-Cháidez et al. 2013).

Moreover, since species differ from one another in tree allometry (Niklas 1995, Chave et al. 2005, Picard et al. 2012), AGB estimates may vary slightly with species representation in a sample. Although we included 18 tree species belonging to the top 25 species that accounted for $95 \%$ of AGB in the studied area, each of these 18 species was represented by only one to seven individuals. This means that our estimates may be slightly biased by the best sampled species (e.g., Lonchocarpus xuul Lundell, Piscidia piscipula (L) Sarg. see Table 1). Thus, the generality of our findings and their potential applicability to other tropical dry forests should be further investigated (ideally using larger, more representative sample sizes) - particularly for large trees (DBH $\geq 10 \mathrm{~cm}$ ). However, we believe that equation 1 provides accurate estimation of AGB for smaller trees and may be more widely applicable, especially to secondary dry forests, since, compared to old-growth forests, small trees make up a greater proportion of AGB in these forests (van Breugel et al. 2011) -which currently make up most of the forested area worldwide (FAO 2010).

Our results also have potential applications to current forest management practices in the Ejido San Agustín, which are based on two harvest cycles: a short cycle of 10 years with a $5 \mathrm{~cm}$ in $\mathrm{DBH}$ minimum harvest diameter of almost all tree and shrub species mostly for charcoal production; and long cycle of 20 years with a $25 \mathrm{~cm}$ in DBH minimum harvest diameter of a few valuable timber species. The results of this study suggest that these harvest practices could be modified to maximize carbon storage, without compromising charcoal production or timber extraction. Thus, instead of harvesting almost all individuals with a minimum DBH of $5 \mathrm{~cm}$ for charcoal or biofuel production, all but one stem of tree species could be harvested (including branches), leaving the straightest and least branched stem to continue growing towards the size threshold $(12.2 \mathrm{~m} \mathrm{H} ; 9.9 \mathrm{~cm} \mathrm{DBH})$ at which allocation to AGB growth (hence carbon storage) increases. Once the individuals of timber species attain the minimum diameter for the long cycle, those with the appropriate characteristics could be harvested, leaving all other trees for longterm carbon storage. This would allow maintaining charcoal or biofuel production, selecting the best individuals and stems for timber harvest in the long cycle, and at the same time would reduce forest degradation, to comply with climate change mitigation strategies such as REDD+-thereby diversifying and potentially increasing revenues from forest management.

Our results show that using segmented regression to study individual relationships between variables included in allometric models of AGB allowed identifying a shift in allometry and defining tree size categories for which different equations should be applied. The combined use of these equations produced more precise estimations of AGB than a single equation that assumes unchanging allometric relationships. The shift in allometry detected in this study involved tree height with an inflection point corresponding to the average forest canopy height $(12.2 \mathrm{~m})$. Our results suggest a shift in resource allocation to growth: mostly to height for small $(2.5-9.95 \mathrm{~cm} \mathrm{DBH})$ trees vs mostly to AGB for larger $(\geq 10$ $\mathrm{cm} \mathrm{DBH})$ trees. These findings have potential applications to forest management and clear implications for monitoring, reporting and verification (MRV) of forest emission factors, especially in secondary forests, which are increasing in extent and importance worldwide. Clearly, their generality and applicability need further investigation and validation using larger, more representative samples.

\section{Acknowledgements}

We thank the San Agustín community for granting us permission to fell trees in their Ejido; the staff of Bioasesores A.C. for their help with field work; The Nature Conservancy, USAID-México and CONACYT for providing financial support, and UADY-CCBA and CICY for their logistic support. We also thank Filogonio May, Juan Pablo Caamal and Dinosca Rondón for their help with field work, and Dr. Argenis Mora for guidance with statistical analyses. The comments of two anonymous reviewers helped to improve the clarity and impact of this paper.

\section{Literature Cited}

Anderson-Teixeira KJ, Davies SJ, Bennett AC, GonzálezAkre EB, Muller-Landau HC, Joseph Wright S, Abu Salim K, Almeyda Zambrano AM, Alonso A, Baltzer JL, Basset Y, Bourg NA, Broadbent EN, Brockelman WY, Bunyavejchewin S, Burslem DFRP, Butt N, Cao M, Cárdenas D, Chuyong GB, Clay K, Cordell S, Dattaraja HS, Deng X, Detto M, Du X, Duque A, Erikson DL, Ewango CEN, Fischer GA, Fletcher C, Foster RB, Giardina CP, Gilbert GS, Gunatilleke N, Gunatilleke S, Hao Z, Hargrove WW, Hart TB, Hau BCH, He F, Hoffman FM, Howe RW, Hubbell SP, Inman-Narahari FM, Jansen PA, Jiang M, Johnson DJ, Kanzaki M, Kassim AR, Kenfack D, Kibet S, Kinnaird MF, Korte L, Kral K, Kumar J, Larson AJ, Li Y, Li X, Liu S, Lum SKY, Lutz JA, Ma K, Maddalena DM, Makana JR, Malhi Y, Marthews T, Mat Serudin R, McMahon SM, McShea WJ, Memiaghe HR, Mi X, Mizuno T, Morecroft M, Myers JA, Novotny V, de Oliveira AA, Ong PS, Orwig DA, Ostertag R, den Ouden J, Parker GG, Phillips RP, Sack L, Sainge MN, Sang W, Sri-ngernyuang K, Sukumar R, Sun IF, Sungpalee W, Suresh HS, Tan S, Thomas SC, Thomas DW, Thompson J, Turner BL, Uriarte M, Valencia R, Vallejo MI, Vicentini A, Vrška T, Wang X, Wang X, Weiblen G, Wolf A, Xu H, Yap S, Zimmerman J. 2015. CTFS-ForestGEO: a worldwide network monitoring forests in an era of global change. Global Change Biology 21: 528-549.

DOI: https://doi.org/10.1111/gcb.12712

Angelsen A, Brockhaus M, Sunderlin WD, Verchot LV. 2012. Analysing REDD+: Challenges and choices. Jakarta: Center for International Forestry Research, CIFOR. DOI: https://doi.org/10.17528/cifor/003805

Baccini A, Goetz SJ, Walker WS, Laporte NT, Sun M, SullaMenashe D, Hackler J, Beck PSA, Dubayah R, Friedl MA, Samanta S, Houghton RA. 2012. Estimated carbon dioxide 
emissions from tropical deforestation improved by carbondensity maps. Nature Climate Change 2: 182-185. DOI: https://doi.org/10.1038/NCLIMATE1354

Barrera-Bassols N, Toledo VM. 2005. Ethnoecology of the Yucatec Maya: symbolism, knowledge and management of natural resources. Journal of Latin American Geography 4: 9-41.

Bautista F, Frausto O, Ihl T, Aguilar Y. 2015. Actualización del mapa de suelos de Yucatán, México: enfoque geomorfopedológico y WRB. Ecosistemas y Recursos Agropecuarios 2: 303-315.

Bongers F, Chazdon R, Poorter L, Peña-Claros M. 2015. The potential of secondary forests. Science 348: 642-643. DOI: https://doi.org/10.1126/science.348.6235.642-c

Brown S. 1997. Estimating biomass and biomass change of tropical forests: A Primer Forest Forestry Papers 134: 55 p.

Caballero F. 2011. Selección de modelos mediante criterios de información en análisis factorial. Ph.D Thesis, Universidad de Granada.

Chaplin-Kramer R, Ramler I, Sharp R, Haddad NM, Gerber JS, West PC, Mandle L, Engstrom P, Baccini A, Sim S, Mueller C, King H. 2015. Degradation in carbon stocks near tropical forest edges. Nature Communications $\mathbf{6}$.

DOI: http://dx.doi.org/10.1038/ncomms10158

Chave J, Condit R, Aguilar S, Hernández A, Lao S, Pérez R. 2004. Error propagation and scaling for tropical forest biomass estimates. Philosophical Transactions of the Royal Society of London B: Biological Sciences 359: 409-420. DOI: https://doi.org/10.1098/rstb.2003.1425

Chave J, Andalo C, Brown S, Cairns MA, Chambers JQ, Eamus D, Fölster H, Fromard F, HiguchiN, Kira T, Lescure J-P, Nelson BW, Ogawa H, Puig H, Riéra B, Yamakura T. 2005. Tree allometry and improved estimation of carbon stocks and balance in tropical forests. Oecologia 145: 87-99. DOI: https://doi.org/10.1007/s00442-005-0100-x

Chave J, Muller-Landau H, Baker TR, Easdale TA, ter Steege H, Webb CO. 2006. Regional and phylogenetic variation of wood density across 2456 Neotropical tree species. Ecological Applications 16: 2356-2367.

DOI: $\quad$ https://doi.org/10.1890/1051-0761(2006)016[2356: RAPVOW]2.0.CO;2

Chave J, Réjou-Méchain M, Búrquez A, Chidumayo E, Colgan MS, Delitti WBC, Duque A, Eid T, Fearnside PM, Goodman RC, Henry M, Martínez-Yrízar A, Mugasha WA, Muller-Landau HC, Mencuccini M, Nelson BW, Ngomanda A, Nogueira EM, Ortiz-Malavassi E, Pélissier R, Ploton P, Ryan CM, Saldarriaga JG, Vieilledent G. 2014. Improved allometric models to estimate the aboveground biomass of tropical trees. Global Change Biology 20: 3177-3190. DOI: https://doi.org/10.1111/gcb.12629

Chazdon RL, Broadbent EN, Rozendaal DMA, Bongers F, Zambrano AMA, Aide TM, Balvanera P, Becknell JM, Boukili V, Brancalion PHS, Craven D, de Almeida-Cortez JS, Cabral GAL, de Jong B, Denslow JS, Dent DH, DeWalt SJ, Dupuy JM, Durán SM, Espírito-Santo MM, Fandino MC, César RG, Hall JS, Hérnandez-Stefanoni JL, Jakovac CC, Junqueira AB, Kennard D, Letcher SG, Lohbeck M, Martínez-Ramos M, Massoca P, Meave JA, Mesquita R, Mora
F, Muñoz R, Muscarella R, Nunes YRF, Ochoa-Gaona S, Orihuela-Belmonte E, Peña-Claros M, Pérez-García EA, Piotto D, Powers JS, Rodríguez-Velázquez J, Romero-Pérez IE, Ruiz J, Saldarriaga JG, Sánchez-Azofeifa A, Schwartz NB, Steininger MK, Swenson NG, Uriarte M, van Breugel M, van der Wal H, Veloso MDM, Vester H, Vieira ICG, Vizcarra Bentos T, Williamson GB, Poorter L. 2016. Carbon sequestration potential of second-growth forest regeneration in the Latin American tropics. Science Advances 2: e1501639 DOI: https://doi.org/10.1126/sciadv.1501639

Chen Q, Laurin GV, Valentini R. 2015. Uncertainty of remotely sensed aboveground biomass over an African tropical forest: Propagating errors from trees to plots to pixels. Remote Sensing of Environment 160: 134-143.

DOI: https://doi.org/10.1016/j.rse.2015.01.009

CONAFOR [Comisión Nacional Forestal]. 2013. Inventario Nacional y de Suelos. Manual y procedimientos para el muestreo de campo. Zapopan, Jalisco: CONAFOR.

Dixon R, Solomon AM, Brown S, Houghton REA, Trexler MC, Wisniewski J. 1994. Carbon pools and flux of global forest ecosystems. Science 263: 185-189.

DOI: https://doi.org/10.1126/science.263.5144.185

Dupuy JM, Hernández-Stefanoni JL, Hernández-Juárez RA, Tetetla-Rangel E, López-Martínez JO, Leyequién-Abarca E, Tun-Dzul F, May-Pat F. 2012. Patterns and correlates of tropical dry forest structure and composition in a highly replicated chronosequence in Yucatan, Mexico. Biotropica 44: 151-162. DOI: https://doi.org/10.1111/j.1744-7429.2011.00783.x

FAO. 2010. Global Forest Resources Assessment 2010 Main report. Food and

Agriculture Organization of the United Nations (FAO). 163. ISBN 978-92-5-106654-6

Feldpausch TR, Lloyd J, Lewis SL, Brienen RJW, Gloor M, Monteagudo Mendoza A, López-González G, Banin L, Abu Salim K, Affum-Baffoe K, Alexiades M, Almeida S, Amaral I, Andrade A, Aragão L EOC, Araujo Murakami A, Arets E JMM, Arroyo L, Aymard C GA, Baker TR, Bánki OS, Berry NJ, Cardozo N, Chave J, Comiskey JA, Álvarez E, de Oliveira A, Di Fiore A, Djagbletey G, Domingues TF, Erwin TL, Fearnside PM, França MB, Freitas MA, Higuchi N, Honorio CE, Iida Y, Jiménez E, Kassim AR, Killeen TJ, Laurance WF, Lovett JC, Malhi Y, Marimon BS, MarimonJunior BH, Lenza E, Marshall AR, Mendoza C, Metcalfe DJ, Mitchard ETA, Neill DA, Nelson BW, Nilus R, Nogueira EM, Parada A, Peh KSH, Pena Cruz A, Peñuela MC, Pitman NCA, Prieto A, Quesada CA, Ramírez F, Ramírez-Angulo H, Reitsma JM, Rudas A, Saiz G, Salomão RP, Schwarz M, Silva N, Silva-Espejo JE, Silveira M, Sonké B, Stropp J, Taedoumg HE, Tan S, ter Steege H, Terborgh J, TorelloRaventos M, van der Heijden GMF, Vásquez R, Vilanova E, Vos VA, White L, Willcock S, Woell H, Phillips OL. 2012. Tree height integrated into pantropical forest biomass estimates. Biogeosciences 9: 3381-3403.

DOI: https://doi.org/10.5194/bg-9-3381-2012

Flores-Guido JS, Espejel-Carvajal I. 1994. Tipos de Vegetación de la Península de Yucatán. Etnoflora Yucatanense. 3. ISBN: 9686843442

Fonseca W, Alice F, Rey JM. 2009. Modelos para estimar la 
biomasa de especies nativas en plantaciones y bosques secundarios en la zona Caribe de Costa Rica. Bosque 30: 36-47. DOI: http://dx.doi.org/10.4067/S0717-92002009000100006

García E. 1973. Modificaciones al sistema de clasificación Climática de Köppen para adaptarlo a las condiciones de la República Mexicana. Instituto de Geografía, Universidad Nacional Autónoma de México.

Gayon J. 2000. History of the Concept of Allometry 1. American Zoologist 40, 748-758. https://doi.org/10.1093/icb/40.5.748

Hernández-Stefanoni JL, Dupuy JM. 2008. Effects of landscape patterns on species density and abundance of trees in a tropical subdeciduous forest of the Yucatan Peninsula. Forest Ecology and Management 255: 3797-3805.

DOI: https://doi.org/10.1016/j.foreco.2008.03.019

Hernández-Stefanoni JL, Dupuy JM, Johnson KD, Birdsey R, Tun-Dzul F, Peduzzi A, Caamal-Sosa, JP, Sánchez-Santos G, López-Merlín D. 2014. Improving species diversity and biomass estimates of tropical dry forests using airborne LiDAR. Remote Sensing 6: 4741-4763.

DOI: https://doi.org/10.3390/rs6064741

Hui D, Deng Q, Tian H, Luo Y. 2016. Climate Change and Carbon Sequestration in Forest Ecosystems. In. Chen WY, Suzuki T, Lackner M. eds. Handbook of Climate Change Mitigation and Adaptation. New York: Springer 555-594. DOI: https://doi.org/10.1007\%2F978-1-4614-6431-0_13-2 eISBN: 978-1-4614-6431-0

Jucker T, Caspersen J, Chave J, Antin C, Barbier N, Bongers F, Dalponte M, van Ewijk KY, Forrester DI, Haeni M, Higgins SI, Holdaway RJ, Iida Y, Lorimer C, Marshall PL, Momo S, Moncrieff GR, Ploton P, Poorter L, Rahman KA, Schlund M, Sonké B, Sterck FJ, Trugman AT, Usoltsev VA, Vanderwel MC, Waldner P, Wedeux BMM, Wirth C, Wöll H, Woods M, Xiang W, Zimmermann NE, Coomes DA. 2017. Allometric equations for integrating remote sensing imagery into forest monitoring programmes. Global Change Biology 23: 177190. DOI: https://doi.org/10.1111/gcb.13388

Klepper O, Rouse DI. 1991. A procedure to reduce parameter uncertainty for complex models by comparison with real system output illustrated on a potato growth model. Agricultural Systems 36: 375-395.

DOI: https://doi.org/10.1016/0308-521X(91)90067-K

Le Quéré C, Moriarty R, Andrew RM, Canadell JG, Sitch S, Korsbakken JI, Friedlingstein P, Peters GP, Andres RJ, Boden TA, Houghton RA, House JI, Keeling RF, Tans P, Arneth A, Bakker DCE, Barbero L, Bopp L, Chang J, Chevallier F, Chini LP, Ciais P, Fader M, Feely RA, Gkritzalis T, Harris I, Hauck J, Ilyina T, Jain AK, Kato E, Kitidis V, Klein Goldewijk K, Koven C, Landschützer P, Lauvset SK, Lefèvre N, Lenton A, Lima ID, Metzl N, Millero F, Munro DR, Murata A, Nabel JEMS, Nakaoka S, Nojiri Y, O'Brien K, Olsen A, Ono T, Pérez FF, Pfeil B, Pierrot D, Poulter B, Rehder G, Rödenbeck C, Saito S, Schuster U, Schwinger J, Séférian R, Steinhoff T, Stocker BD, Sutton AJ, Takahashi T, Tilbrook B, van der Laan-Luijkx IT, van der Werf GR, van Heuven S, Vandemark D, Viovy N, Wiltshire A, Zaehle S, Zeng N. 2015. Global Carbon Budget 2015, Earth Syst. Sci. Data, 7, 349-396.

DOI: https://doi.org/10.5194/essd-7-349-2015.
Loague K, Green RE. 1991. Statistical and graphical methods for evaluating solute transport models: Over-view and applications. Journal of Contaminant Hydrology 7: 51-73. DOI: https://doi.org/10.1016/0169-7722(91)90038-3

López-Martínez JO, Sanaphre-Villanueva L, Dupuy JM, Hernández-Stefanoni JL, Meave JA, Gallardo-Cruz JA. 2013. $\beta$-Diversity of functional groups of woody plants in a tropical dry forest in Yucatan. PLOS ONE 8: e73660. DOI: https://doi.org/10.1371/journal.pone.0073660

Malhi, Y, Wood D, Baker TR, Wright J, Phillips OL, Cochrane T, Meir P, Chave J, Almeida S, Arroyo L, Higuchi N, Killeen TJ, Laurance SG, Laurance WF, Lewis SL, Monteagudo A, Neill DA, Núnez Vargas P, Pitman NCA, Quesada CA, Salomao, R, Silva JNM, Torres Lezama, A, Terborgh, J, Vasquez-Martínez R, Vinceti B. 2006. The regional variation of aboveground live biomass in old-growth Amazonian forests. Global Change Biology 12: 1107-1138.

DOI: https://doi.org/10.1111/j.1365-2486.2006.01120.x

Medina-Peralta S, Vargas-Villamil L, Navarro-Alberto J, CanulPech C, Peraza-Romero S. 2010. Comparación de medidas de desviación para validar modelos sin sesgo, sesgo constante o proporcional. Ecosistemas y Recursos Agropecuarios 26: 255-263.

Mermoz S, Réjou-Méchain M, Villard L, Le Toan T, Rossi V, Gourlet-Fleury S. 2015. Decrease of L-band SAR backscatter with biomass of dense forests. Remote Sensing of Environment 159: 307-317.

DOI: https://doi.org/10.1016/j.rse.2014.12.019

Midgley JJ. 2003. Is bigger better in plants? The hydraulic costs of increasing size in trees. Trends in Ecology and Evolution 18: 5-6. DOI: https://doi.org/10.1016/S0169-5347(02)00016-2

Molto Q, Hérault B, Boreux JJ, Daullet M, Rousteau A, Rossi V. 2013. Predicting tree heights for biomass estimates in tropical forests. Biogeosciences Discussions 10: 8611-8635. DOI: https://doi.org/10.5194/bgd-10-8611-2013

Muggeo VM. 2008. Segmented: an R package to fit regression models with broken-line relationships. $R$ News 8: 20-25.

Návar-Cháidez J, Rodríguez-Flores FDJ, Domínguez-Calleros PA. 2013. Ecuaciones alométricas para árboles tropicales: aplicación al inventario forestal de Sinaloa, México. Agronomía Mesoamericana 24: 347-356.

Niklas KJ. 1995. Size-dependent allometry of tree height, diameter and trunk-taper. Annals of Botany 75: 217-227. DOI: https://doi.org/10.1006/anbo.1995.1015

Pan Y, Birdsey RA, Fang J, Houghton R, Kauppi PE, Kurz WA, Phillips OL, Shvidenko A, Lewis SL, Canadell JG, Ciais P, Jackson RB, Pacala S, McGuire AD, Piao S, Rautiainen A, Sitch S, Hayes D, Watson C. 2011. A large and persistent carbon sink in the world's forests. Science 333: 988-993. DOI: https://doi.org/10.1126/science.1201609

Picard N, Saint-Andre L, Henry M. 2012. Manual de Construcción de Ecuaciones Alométricas para Estimar el Volumen y la Biomasa de los Árboles: del Trabajo de Campo a la Predicción. CIRAD y FAO. E-ISBN 978-92-5-307347-4

Poorter L, Bongers F, Aide TM, Almeyda Zambrano AM, Balvanera P, Becknell JM, Bentos TV, Boukili VK, Broadbent EN, Chazdon RL, Craven D, Cabral GAL, de Almeida-Cor- 
tez JS, de Jong B, Denslow JS, Dent DH, DeWalt SJ, Dupuy JM, Durán SM, Espírito-Santo MM, Fandino MC, Hall JS, Hernández-Stefanoni JL, Jakovac CC, Junqueira AB, Kennard DK, Letcher SG, Lohbeck M, Marín-Spiotta E, Martínez-Ramos M, Massoca PES, Meave JA, Mesquita RCG, Mora F, Muñoz R, Muscarella R, Nunes YRF, Ochoa-Gaona S, Orihuela-Belmonte E, Peña-Claros M, Pérez-García EA, Piotto D, Powers JS, Rodríguez-Velazquez J, Romero-Pérez IE, Ruíz J, Sanchez-Azofeifa GA, Swenson N, Toledo M, Uriarte M, van Breugel M, van der Wal H, Veloso MDM, Williamson GB, Rozendaal DMA. 2016. Biomass resilience of Neotropical secondary forests. Nature 530: 211-214. DOI: http://dx.doi.org/10.1038/nature16512

R Core Team (2018) R: A Language and Environment for Statistical Computing. R Foundation for Statistical Computing, Vienna, Austria. <https://www.R-project.org/> (accessed October 24, 2018)

Ramírez-Ramírez G, Dupuy-Rada JM, Ramírez-Avilés L, Solorio-Sánchez FJ. 2017. Evaluación de ecuaciones alométricas de biomasa aérea enselvas secas de Yucatán, México. Madera y Bosques 23: 163:179. DOI: https://doi.org/10.21829/ myb.2017.2321452

Sanaphre-Villanueva L, Dupuy JM, Andrade J, Reyes-García C, Paz H, Jackson PC. 2016. Functional diversity of small and large trees along secondary succession in a tropical dry forest. Forests 7: 163. DOI: https://doi.org/10.3390/f7080163

Segura M, Andrade HJ. 2008. ¿Cómo construir modelos alométricos de volumen, biomasa o carbono de especies leñosas perennes? Agroforestería en las Américas 46: 89-96.

Stas SM, Rutishauser E, Chave J, Anten N, Laumonier Y. 2017. Estimating the aboveground biomass in an old secondary forest on limestone in the Moluccas, Indonesia: Comparing locally developed versus existing allometric models. Forest Ecology and Management 389: 27-34.

DOI: https://doi.org/10.1016/j.foreco.2016.12.010

Tedeschi LO. 2006. Assessment of the adequacy of mathematical models. Agricultural Systems 89: 225-247.

DOI: https://doi.org/10.1016/j.agsy.2005.11.004

Timothy D, Onisimo M, Riyad I. 2016. Quantifying aboveground biomass in African environments: A review of the trade-offs between sensor estimation accuracy and costs. Tropical Ecology 57: 393-405.

UNFCCC [United Nations Framework Convention on Climate Change]. 2007. Report of the conference of the parties on its thirteenth session, held in Bali from 3 to 15 December 2007. Available at: <http://unfccc.int/resource/docs/2007/ cop13/eng/06a01.pdf $>$ (accessed May 23, 2018).

Urquiza-Haas T, Dolman PM, Peres CA. 2007. Regional scale variation in forest structure and biomass in the Yucatan Peninsula, Mexico: effects of forest disturbance. Forest Ecology and Management 247: 80-90.

DOI: https://doi.org/10.1016/j.foreco.2007.04.015

Van Breugel M, Ransijn J, Craven D, Bongers F, Hall JS. 2011. Estimating carbon stock in secondary forests: decisions and uncertainties associated with allometric biomass models. Forest Ecology and Management 262: 1648-1657. DOI: https://doi.org/10.1016/j.foreco.2011.07.018

Weiner J. 2004. Allocation, plasticity and allometry in plants. Perspectives in Plant Ecology, Evolution and Systematics 6: 207-215. DOI: https://doi.org/10.1078/1433-8319-00083

Yang J, Greenwood DJ, Rowell DL, Wadsworth GA, Burns IG. 2000. Statistical methods for evaluating a crop nitrogen simulation model, N_ABLE. Agricultural Systems 64: 37-53. DOI: https://doi.org/10.1016/S0308-521X(00)00010-X

Editorial Assistance: Jordan Golunov Figueroa

Author contributions: GRR conceived the idea, designed and performed the sampling, analysed the data, wrote the paper, and reviewed drafts and revised versions of the paper. LRyA discussed the idea, participated in the sampling design, and reviewed drafts and revised versions of the paper. FJSS discussed the idea, participated in the sampling design, and reviewed drafts and revised versions of the paper. JANA participated in the analyses of data and reviewed drafts and revised versions of the paper. JMDR discussed the idea, participated in the sampling design and data analysis, wrote the paper, and reviewed drafts and revised versions of the paper. 